\title{
INCIDENCE OF NON-TUMOR DISEASES OF DIGESTIVE ORGANS IN PERSONS AGED OF 18 YEARS OLD AND OLDER EVACUATED FROM 30 KILOMETER EXCLUSION ZONE IN POST-ACCIDENT PERIOD [1992-2016]
}

Kapustynska O.A., Prykashchykova K.Ye., Yaroshenko Zh.S., Kostiuk H.V., Lukianiuk V.O., Olepir O.V., Syrovenko V.I., Lytvyniuk I.V., Polianska V.M.

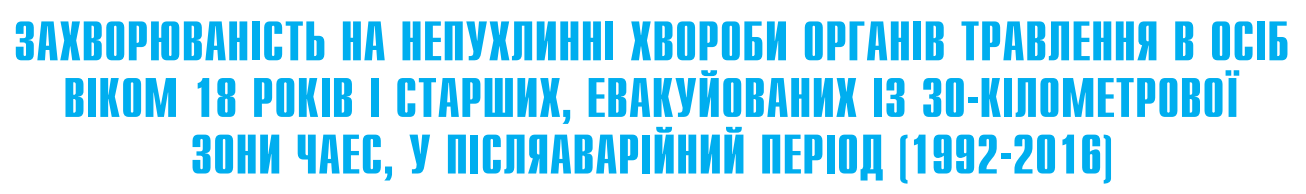

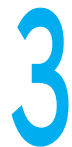

КАПУСТИНСЬКА О.А., ПРИКАЩИКОВА К.Є., ЯРОШЕНКО Ж.С., КОСТЮК Г.В., лУК'янЮК В.О., ОЛЕПІР О.В.,

СИРОВЕНКО В.І., ЛИТВИНЮК І.В., ПОЛЯНСЬКА В.М.

ДУ «Національний науковий центр радіаційної медицини НАМН України», м. Київ а понад тридцять років після техногенної аварії на Чорнобильській атомній електростанції (ЧАЕС) епідеміологічні дослідження засвідчили негативні зміни у стані здоров'я населення, яке зазнало одноразового впливу радіаційного випромінювання [1-3]. У публікаціях післяаварійного періоду деякі автори зазначали, що у структурі непухлинної захворюваності пріоритетну роль відіграють хвороби системи кровообігу, органів травлення, нервової системи й органів чуття, кістковом'язової системи та органів дихання [4, 5]. Дослідники виявили, що під дією «малих доз» (1-5 Гр) радіації та у віддаленому періоді виникають значні зміни в організмі. Внаслідок тривалої, протягом кількох десятирічь, дії радіаційних і нерадіаційних факторів (довкілля, соціально-психологічних) виникають медичні неспецифічні та стохастичні ефекти у стані здо-
ЗАХВОРЮВАНІСТЬ НА НЕПУХЛИННІ ХВОРОБИ ОРГАНІВ ТРАВЛЕННЯ В ОСІБ ВІКОМ 18 РОКІВ I СТАРШИХ, ЕВАКУЙОВАНИХ

ІЗ ЗО-КІЛОМЕТРОВОЇ ЗОНИ ЧАЕС,

У ПІСЛЯАВАРІЙНИЙ ПЕРІОД (1992-2016)

Капустинська О.А., Прикащикова К.Є., Ярошенко Ж.С., Костюк Г.В., Лук'янюк В.О., Олепір О.В., Сировенко В.І.,

Литвинюк І.В., Полянська В.М.

ДУ «Національний науковий центр радіаційної медицини НАМН України», м. Київ

Мета. Епідеміологічний аналіз захворюваності на непухлинні хвороби органів травлення в евакуйованих осіб віком 18 років і старших, за післяаварійний період спостереження.

Матеріали та методи. У післяаварійний період протягом 1992-2016 років проведено епідеміологічне дослідження захворюваності на непухлинні хвороби органів травлення у 7143 осіб віком 18 років і старших (2198 чоловіків та 4945 жінок), евакуйованих із 30-кілометрової зони Чорнобильської АЕС. Для оцінювання захворюваності на хвороби органів травлення досліджуваних осіб вивчалася структура захворювань за статистичною міжнародною класифікацією хвороб десятого перегляду (MKX-10) за інформаційною базою клініко-епідеміологічного реєстру ННЦРМ АМН України.

Результати. У результаті дослідження структури захворювань органів травлення встановлено, що 91,05\% належало соматичній патології за класом «Хвороби органів травлення». Здебільшого здоров'я досліджуваних осіб за цим класом погіршилося через розвиток хвороб порожнини рота, слинних залоз та щелеп, що становлять найбільшу складову $(47,17 \%)$, та хвороб стравоходу, шлунка та дванадцятипалої кишки (34,39\%). Значну втрату здоров'я спричинили також хвороби жовчного міхура, жовчовивідних шляхів та підшлункової залози, хронічних гепатитів та цирозу $(8,13 \%)$, неінфекційний ентерит та коліт, інші хвороби кишечника (1,36\%). Лише 8,9\% припадало на патологію органів травлення серед інших класів МКX-10: «Деякі інфекційні та паразитарні хвороби (АОО-В99)», «Новоутворення (СО0D48)», «Вроджені аномалії (вади розвитку), деформації та хромосомні порушення, (Q00Q99)». Структура захворюваності незалежно від статі характеризується ідентичністю захворювань та співвідношенням величин їхніх показників у структурі загальної когорти. Проте жінки більше страждали на хвороби жовчного міхура, жовчовивідних шляхів та підшлункової залози, хвороби порожнини рота, чоловіки - на хвороби стравоходу, шлунка та дванадцятипалої кишки.

Висновки. Визначення структури хвороб на прикладі захворювань органів травлення в осіб віком 18 років і старших, евакуйованих із 30-кілометрової зони Чорнобильської AEC, дає змогу виявити пріоритетні нозологічні форми для подальшого з'ясування детермінованого зв'язку впливу іонізуючого випромінювання на стан здоров'я потерпілих для проведення запобіжних заходів.

Ключові слова: евакуйовані, хвороби органів травлення, епідеміологічне дослідження.

() Капустинська О.А., Прикащикова К.Є., Ярошенко Ж.С., Костюк Г.В., Лук'янюк В.О., Олепір О. В., Сировенко В. І., Литвинюк І.В., Полянська В.М. СТАТТЯ, 2020. 
ров'я потерпілих. Шлунковокишковий тракт в умовах Чорнобильської аварії належить до основних тканинмішеней дії пошкоджувальних факторів променевої і непроменевої природи [6, 7]. За даними Е.О. Саркісова та ін., захворювання системи травлення посідають друге-третє місця серед непухлинних хвороб в учасників ліквідації аварії на ЧАЕС, за результатами моніторингу стану їхнього здоров'я. Також встановлено, що найбільш поширеними $€$ ерозивно-виразкова патологія шлунка і дванадцятипалої кишки, захворювання печінки [8]. Водночас у науковій літературі $\epsilon$ поодинокі дані про розвиток хвороб органів травлення в осіб, евакуйованих із 30-кілометрової зони YAEC.

Мета дослідження. Епідеміологічний аналіз захворюваності на непухлинні хвороби органів травлення в евакуйованих осіб віком 18 років і старших у післяаварійний період спостереження.

Матеріал і методи дослідження. Епідеміологічний аналіз захворюваності на хвороби органів травлення в осіб, евакуйованих із 30-кілометрової зони ЧАЕС, проведено за 1992-2016 роки. Когорта обстежених становила 7143 особи, у тому числі 2198 чоловіків та 4945 жінок. Вік потерпілих під час клінікоепідеміологічного обстеження становив 18 років і більше. Доза іонізувального випромінювання, отриманого у зоні відчуження досліджуваними особами, становить від 0,003 Зв до 0,36 Зв [9]. Динамічне поглиблене вивчення стану здоров'я потерпілих проводилося один раз на два роки у поліклініці радіаційного реєстру (ПРР) за програмою клініко-епідеміологічного реєстру (KЕP), розробленою ННЦРМ НАМН України.

Дані результатів медичного обстеження реєструвалися в автоматизованій науково-інформаційній базі КЕР. Систематизація зареєстрованих захворювань органів трав-

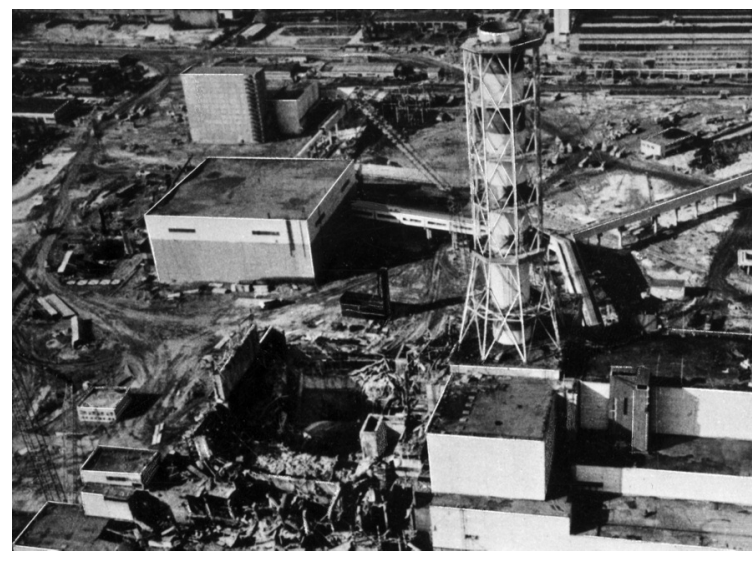

ПРОБЛЕМИ ЧОРНОБИЛЯ

лення проводилася за статистичною міжнародною класифікацією хвороб десятого перегляду (MKX-10). Для оцінювання захворюваності на хвороби органів травлення використовувалися основні епідеміологічні показники структури (C - частина у відсотках, яку має нозологічна форма серед усіх вперше виявлених хвороб) [10].

Результати дослідження. За час медичного обстеження (1992-2016) у ПРР ННЦРМ АМН України за програмою КЕР досліджено стан здоров'я 7143 осіб, евакуйованих із 30-кілометрової зони ЧАЕС. Відповідно до МКX-10 зареєстровано 13532 випадки (100\%) вперше виявлених хвороб органів травлення: у 2198 чоловіків - 3298 випадків $(24,37 \%)$, у 4945 жінок 10234 (75,63\%) нозологічні форми.

Прояв вперше виявлених захворювань органів травлення відбувся за чотирма класами MКX-10: «Деякі інфекційні та паразитарні хвороби, А00В99)» (0,04\%), «Новоутворення, C00-D48)» (3,78\%), «Хвороби органів травлення, К00-К93)» (91,05\%), «Вроджені аномалії (вади розвитку), деформації та хромосомні порушення, Q00-Q99» (5,08\%). У кожному із зазначених класів, в яких зафіксовано хвороби органів травлення, визначені основні групи захворювань. Серед інфекційних захворювань $є$ кишкові інфекції та прозойні хвороби $(0,03 \%)$. Новоутворення представлені переважно доброякісними (3,72\%) та злоякісними новоутвореннями $(0,05 \%)$ верхніх відділів травної системи, шлунка, під- шлункової залози, ободової кишки. Вроджені аномалії на 4,86\% мають вади верхніх відділів травного тракту. 3 цих чотирьох класів хвороб органів травлення 12321 випадок віднесено до класу «Хвороби органів травлення». Таку чисельність захворювань прийняли за 100\% для вивчення структури непухлинної захворюваності за групами хвороб за цим класом.

Оцінювання структури хвороб за цим класом надало можливість встановити наявність пріоритетності розвитку деяких захворювань у потерпілих за роки спостереження (табл. 1). Найбільша захворюваність спостерігалася на хвороби порожнини рота, слинних залоз та щелеп, що становить майже половину 3 усіх хвороб органів травлення. Другою складовою за величиною показника у структурі є група хвороб стравоходу, шлунка та дванадцятипалої кишки. Обидві ці групи хвороб відіграють основну роль у розвитку непухлинної захворюваності органів травлення $(81,56 \%)$.

Значні частки у структурі захворюваності належать хворобам жовчного міхура, жовчовивідних шляхів та підшлункової залози, хворобам печінки. Решта непухлинних хвороб органів травлення за показником $€$ незначною або відсутня у структурі захворюваності.

Структуру захворюваності в осіб, евакуйованих із Чорнобильської зони відчуження, залежно від статі, подано на рисунку 1. У чоловіків і жінок виявлено ідентичність у структурі захворювань та 
INCIDENCE OF NON-TUMOR DISEASES OF DIGESTIVE ORGANS IN PERSONS AGED OF 18 YEARS OLD AND OLDER EVACUATED FROM 30 KILOMETER EXCLUSION ZONE IN POST-ACCIDENT PERIOD (1992-2016) Kapustynska O.A., Prykashchykova K. Ye., Yaroshenko Zh.S., Kostiuk H.V., Lukianiuk V.O., Olepir O.V., Syrovenko V.I., Lytvyniuk I.V., Polianska V.M.

State Institution «National Scientific Center of Radiation Medicine, NAMS Ukraine", Kyiv

Objective: We carried out the epidemiological analysis of the incidence of non-tumor diseases of digestive organs in the people evacuated from the 30-kilometer zone of the Chornobyl NPP at the age of 18 years old and older during the post-accident observation period.

Materials and methods: In the post-accident period during 1992-2016, we performed an epidemiologic study of the incidence of non-tumor diseases of the digestive system in 7,143 people (2,198 men and 4,945 women) aged 18 years old and older evacuated from the 30-kilometer zone of the Chornobyl NPP. To assess the digestive disease incidence in the examined people, we studied a structure of the diseases according to the international statistical classification of the diseases of the tenth revision (ICD-10) by the information base of the clinical and epidemiological register of the NACRM NAMSU.

Results: As a result of the study of the structure of digestive system diseases, it was found that $91.05 \%$ belonged to somatic pathology by the Digestive Diseases' class. The health of the examined by this class persons deteriorated mainly due to the the development of the diseases of oral cavity, salivary glands and jaws, which made up the largest component $(47,17 \%)$ and the diseases of esophagus, stomach, and duodenum (34,39\%). But a significant loss of health was caused by the diseases of the gall bladder, biliary tract and pancreas, chronic hepatitis and cirrhosis (8.13\%), non-infectious enteritis and colitis, and other diseases of the intestine $(1,36 \%)$. Only digestive pathology made up $8,9 \%$ among different classes of ICD-10: "Some infectious and parasitic diseases (A00-B99)», «Tumors (C00-D48)», "Congenital abnormalities (malformations), deformities and chromosomal abnormalities (Q00-Q99)». Irrespective of gender, the morbidity structure of males and females is characterized by the identity of the diseases and the ratio of indicators in the structure of the overall cohort. But females suffered more from gall bladder disease, biliary tract and pancreas disease, oral cavity disease, the malesfrom esophageal, stomach, and 12 duodenal diseases.

Conclusions: Determination of the structure of the diseases on the example of diseases of the digestive organsamong the people aged of 18 years old and older, evacuated from the 30-kilometer zone of the Chornobyl NPP, enables the identification of priority nosological forms for further illustration of the determined relationship of the effect of ionizing radiation on the health status of the suffered for preventive measures.

Keywords: evacuees, digestive organs'diseases, epidemiological study. співвідношенні їхніх величин показників структури загальної когорти. Найбільшим за величиною є показник за групою хвороб порожнини рота, слинних залоз та щелеп, меншим - за групою хвороб стравоходу, шлунка та дванадця-

типалої кишки. Ці групи хвороб є основними складовими у структурі захворювань і у чоловіків $(87,40 \%)$, і у жінок $(79,70 \%)$.

Значними є частки захворювань жовчного міхура, жовчовивідних шляхів та під-

Таблиця 1

Структура непухлинних захворювань органів травлення осіб віком 18 років і старших, евакуйованих із 30-кілометрової зони відчуження ЧАЕС, за 1992-2016 роки спостереження

\begin{tabular}{|l|c|c|c|}
\hline \multicolumn{1}{|c|}{ Хвороби органів травлення } & $\begin{array}{c}\text { Шифр } \\
\text { МКХ-10 }\end{array}$ & $\begin{array}{c}\text { Абс. } \\
\text { число }\end{array}$ & Процент \\
\hline $\begin{array}{l}\text { Хвороби порожнини рота, } \\
\text { слинних залоз та щелеп }\end{array}$ & К00-К14 & 5812 & 47,17 \\
\hline $\begin{array}{l}\text { Хвороби стравоходу, шлунка } \\
\text { та дванадцятипалої кишки }\end{array}$ & K20-К31 & 4237 & 34,39 \\
\hline $\begin{array}{l}\text { Хвороби жовчного міхура, жовчо- } \\
\text { вивідних шляхів та підшлункової залози }\end{array}$ & К80-К87 & 1455 & 11,81 \\
\hline Хвороби печінки & К70-К77 & 650 & 5,28 \\
\hline Неінфекційний ентерит та коліт & K50-К52 & 114 & 0,93 \\
\hline Інші хвороби кишечника & К55-К63 & 53 & 0,43 \\
\hline Грижа & К40-К46 & 0 & 0 \\
\hline Хвороби апендикса & К35-К38 & 0 & 0 \\
\hline Загалом & К00-К93 & 12321 & 100 \\
\hline
\end{tabular}

шлункової залози, печінки. Решта непухлинних хвороб органів травлення за показником незначна або відсутня у структурі захворюваності евакуйованих осіб обох статей. Встановлено різницю величин показників за виявленими хворобами органів травлення у чоловіків і жінок. Величини показника у жінок більші, ніж у чоловіків на такі захворювання: жовчного міхура, жовчовивідних шляхів та підшлункової залози - на 6,7\%, майже наполовину; порожнини рота, слинних залоз та щелеп - на 3,99\%; неінфекційний ентерит і коліт - на 0,64\%, майже на половину величини показника. У чоловіків спостерігалося на 11,69\%, або в 1,4 рази більше випадків хвороб стравоходу, шлунка та дванадцятипалої кишки, ніж у жінок.

Формування груп непухлинних хвороб, поданих у структурі захворюваності органів травлення в евакуйованих 
ЭПИДЕМИОЛОГИЧЕСКИЙ АНАЛИЗ РАЗВИТИЯ НЕОПУХОЛЕВЫХ ЗАБОЛЕВАНИЙ ОРГАНОВ ПИЩЕВАРЕНИЯ У ЛИЦ В ВОЗРАСТЕ 18 ЛЕТ И СТАРШЕ, ЭВАКУИРОВАННЫХ ИЗ 30-КИЛОМЕТРОВОЙ ЗОНЫ ЧАЭС, В ПОСЛЕАВАРИЙНЫЙ ПЕРИОД (1992-2016)

Капустинская О.А., Прикащикова Е.E., Ярошенко Ж.С., Костюк Г.В., ЛукьянюК В.О., Олепир О. В., Сировенко В. И., Литвинюк И. В., Полянская В.М.

ГУ «Национальный научный центр радиационной медицины НАМН Украины», Г. Киев,

Цель исследования заключалась в проведении эпидемиологического анализа неопухолевых заболеваний органов пищеварения у лиц в возрасте 18 лет и старше, эвакуированных из 30-километровой зоны ЧАЭС, за послеварийный период наблюдения.

\section{Материалы и методы исследования.}

Эпидемиологическое исследование неопухолевой заболеваемости органов пищеварения у 7143 человек (2198 мужчин и 4945 женщин), эвакуированных из 30-километровой зоны Чернобыльской АЭС, проведено по данным клинико-эпидемиологического реестра ННЦРМ НАМН Украины. Возраст пострадавших во время обследования составлял 18 лет и старше. Для оценки заболеваемости болезнями системы пищеварения у исследуемых изучалась структура болезней по международной классификации болезней десятого пересмотра (МКБ-10).

Результаты. В результате проведенного эпидемиологического исследования установлено, что болезни органов пищеварения в структуре неопухолевой заболеваемости эвакуированных составляли 91,05\% (класс XI, К00-K93.9) и лишь 8,9\% по группам таких болезней, как «Некоторые инфекционные и паразитарные болезни (АО0-B99)», «Новообразования (C00-D48)», «Врожденные аномалии (пороки развития), деформации и хромосомные нарушения (Q00-Q99)». За годы наблюдения в структуре болезней органов пищеварения преобладают болезни полости рта, слюнных желез и челюстей $(47,17 \%)$, болезни пищевода, желудка и двенадцатиперстной кишки (34,39\%), которые стали основными факторами потери (на 81,56\%) здоровья от всех неопухолевых болезней органов пищеварения исследуемого контингента. Болезни желчного пузыря, желчевыводящих путей и поджелудочной железы, хронические гепатиты и циррозы составляют 8,13\%, неинфекционный энтерит и колит 1,36\%.Структура заболеваемости независимо от пола характеризуется идентичностью заболеваний и соотношений величин показателей в структуре общей когорты. Однако у женщин выявлено больше болезней желчного пузыря, желчевыводящих путей и поджелудочной железы, болезней полости рта, у мужчин - больше болезней пищевода, желудка и двенадцатиперстной кишки.

Выводы. Определение структуры болезней на примере заболеваний органов пищеварения у лиц в возрасте 18 лет и старше, эвакуированных из 30-километровой зоны Чернобыльской АЭС, позволяет выявить приоритетные нозологические формы для дальнейшего выяснения детерминированной связи влияния ионизирующего излучения на состояние здоровья пострадавших для проведения профилактических мероприятий.

Ключевые слова: эвакуированные, болезни органов пищеварения, эпидемиологические исследования. осіб, зумовило розвиток каpiєcy (К02, К03) - 24,20\%; гастритів і дуоденітів (К29) 12,43\%; виразки дванадцятипалої кишки (К26) - 9,31\%; хвороб пульпи та періапікальних тканин (К04) - 8,92\%; хвороб стравоходу (К29) 8,64\%; виразки шлунка (К24) - 4,89\%. Серед хвороб печінки (К70-К77) найбільша частина припадає на хронічний гепатит та цироз (К73-К74) 4,06\%. Серед хвороб жовчного міхура, жовчовивідних шляхів та підшлункової залози найбільше хвороб жовчного міхура (К80-К82) - 4,39\%. 3 цих нозологічних форм сформовано групи хвороб органів травлення у жінок і чоловіків.

Закінчення. Вивчення структури захворюваності на хвороби органів травлення в осіб, евакуйованих із 30-кілометро- вої зони ЧАЕС, обстежених у 18-річному віці і старших у післяаварійні роки (1992-2016)

їхнього життя, показало, що найбільше спостерігалися непухлинні захворювання класу

Рисунок

Структура непухлинних хвороб органів травлення в осіб віком 18 років і старших, евакуйованих із 30-кілометрової зони відчуження ЧАЕС, залежно від статі, за 1992-2016 роки спостереження

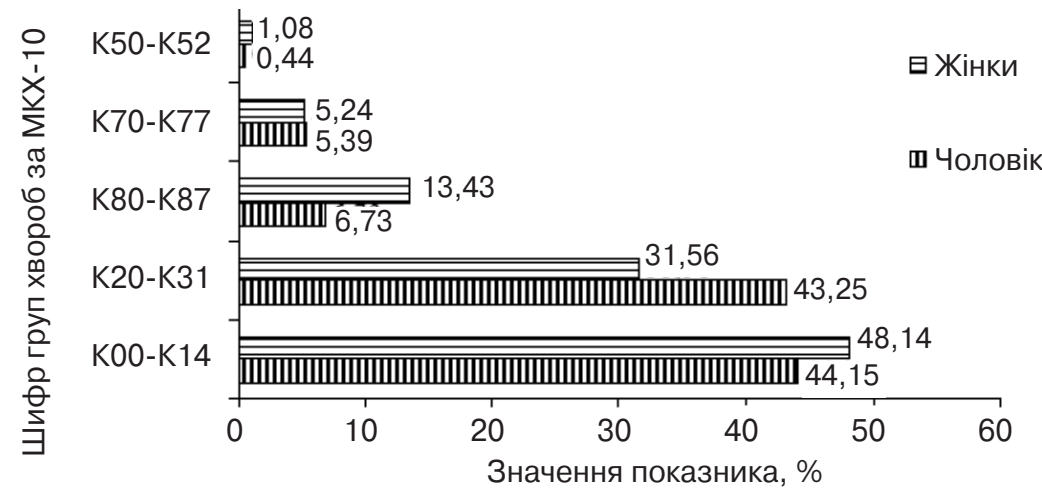

Умовні позначення: К00-К14 - хвороби порожнини рота, слинних залоз та щелеп; К20-КЗ1 - хвороби стравоходу, шлунка та дванадцятипалої кишки; К80 -К87 - хвороби жовчного міхура, жовчовивідних шляхів та підшлункової залози; К70-К77 - хвороби печінки; К50-К52 - неінфекційний ентерит та коліт.

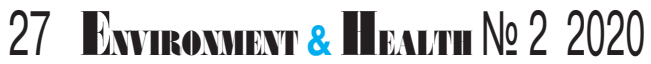


здоров'я органів травлення хвороби жовчного міхура, жовчовивідних шляхів та підшлункової залози, хоча частка їх у структурі на 35,36\% менша (у чотири рази) порівняно 3 хворобами порожнини рота, на 22,78\% менша (втричі) порівняно з хворобами стравоходу, шлунка та дванадцятипалої кишки.

Основним захворюванням серед даної групи хвороб $€$ хвороби жовчного міхура (К80-К82) - 4,39\%. Хвороби печінки лише на 5,28\% проявилися у структурі, а саме: найбільшою захворюваністю на хронічний гепатит та цироз (К73-К74) - 4,06\%. Виявлені неінфекційний ентерит та коліт, інші хвороби кишечника проявилися серед усіх захворювань органів травлення лише на 0,93\% та 0,43\% відповідно.

Структура захворюваності в осіб, евакуйованих із Чорнобильської зони відчуження, незалежно від статі ,характеризується ідентичністю захворювань та співвідношенням їхніх величин показників у структурі загальної когорти. Різниця полягала у більшій захворюваності жінок порівняно з чоловіками на хвороби жовчного міхура, жовчовивідних шляхів та підшлункової залози - удвічі; на хвороби порожнини рота, слинних залоз та щелеп - в 1,1 рази; на неінфекційний ентерит та коліт - майже на половину величини показника (у 2,5 рази). Чоловіки в 1,4 рази більше, ніж жінки хворіють на хвороби стравоходу, шлунка та дванадцятипалої кишки

\section{Висновки}

Визначення структури хвороб на прикладі захворювань органів травлення в осіб віком 18 років і старших, евакуйованих із 30-кілометрової зони Чорнобильської АЕC, дає змогу виявити пріоритетні нозологічні форми для подальшого з'ясування детермінованого зв'язку впливу іонізуючого випромінювання на стан здоров'я потерпілих для проведення запобіжних заходів.

\section{ЛІТЕРАТУРА}

1. Бузунов В.А., Пирогова Е.А., Красникова Л.И. Эпидемиология неопухолевых эффектов ионизирующего облучения. Журн. АМН України. 2006. Т. 12, № 1. C. 174-184.

2. Иванов В.К., Цыб А.Ф. Медицинские радиологические последствия Чернобыля для населения России: оценка радиационных рисков. М. : Медицина, 2010. 392 с.

3. Рожко А.В., Надыров Э.А., Веялкин И.В., Стожаров А.Н., Богдан Е.Л., Никонович С.Н., Семененко О.Ф., Захарова О.Н., Чайкова Ю.В., Чешик А.А. Медицинские последствия аварии на ЧАЭС в республике Беларусь: 30 лет спустя. Медико-биологические проблемы жизнедеятельности. 2016. № 1 (15). С. 31-41.

4. Бузунов В.А., Красникова Л.И., Пирогова Е.А., Терещенко В.М., Войчулене Ю.С.

Эпидемиологические исследования и оценка влияния малых доз ионизирующего излучения на развитие неопухолевых заболеваний у пострадавших вследствие аварии на ЧАЭС. Проблеми радіаційної медицини та радіобіології: зб. наук. пр. К., 2008. Вип. 13. С. 56-67.

5. Красникова Л.И., Бузунов В.А. Риски неопухолевой патологии участников ликвидации последствий Чернобыльской аварии по данным углубленного клинико-эпидемиологического мониторинга. Проблеми радіаційної медицини та радіобіології : зб. наук. пр. К., 2008. Вип. 13. С. 199-208.

6. Комаренко Д.І., Якименко Д.М., Мороз Г.З., Саркісова Е.O.,

Варшавська А.М. Стан органів травлення у постраждалих внаслідок аварії на ЧАЕС. Медичні наслідки аварії на Чорнобильській атомній електростанції /за ред. О.Ф. Возіанова, В.Г. Бебешка, Д.А. Базики. ні 1992-2016 роки їхнього життя. Також погіршили стан 
Київ : ДІА, 2007. С. 318-326.

7. Саркісова Е.О. та ін. Патологія органів системи травлення в осіб, які зазнали впливу малих доз іонізуючого випромінювання. Медичні наслідки Чорнобильської катастрофи: 1986-2011. За ред. А.М. Сердюка, В.Г. Бебешка, Д.А. Базики. Тернопіль: ТДМУ, 2011. C. 614-634.

8. Чумак В.В., Ліхтарьов І.А., Репін В.С. Дози опромінення евакуйованого населення. Чорнобильська катастрофа : монографія. За ред. В.Г. Бар'яхтара. К. : Наукова думка, 1996. С. 420-424.

9. Страпко Н.П., Пирогова Е.А. Методика эпидемиологического мониторинга общих соматических заболеваний взрослого населения, пострадавшего вследствие аварии на ЧАЭС : метод. рек. K., 1993. 32 c.

10. Альбом А., Норелл С. Введение в современную епидемиологию. М., 1996. 122 c.

REFERENCES

1. Buzunov V.A., Pirogova E.A. and

Krasnikova L.I. Epidemiologiya neopukholevykh effektov ioniziruyushchego oblucheniya [Epidemiology of Non-Tumor Effects of Ionizing Radiation]. Zhurnal AMN Ukrainy. 2006 ; 12 (1) : 174-184 (in Russian).

2. Ivanov V.K. and Tsyb A.F. Meditsinskiye radiologicheskiye posledstviya

Chernobylya dlya naseleniya Rossii: otsenka radiatsionnykh riskov [Medical Radiological Consequences of Chernobyl for the Health of the Russian Population: Assessment of Radiation Risk]. Moscow : Meditsina ; 2010 : 392 p. (in Russian).

3. Rozhko A.V., Nadyrov E.A., Veyalkin I.V., Stozharov A.N., Bogdan E.L., Nikonovich S.N. et al. Meditsinskiye posledstviya avarii na ChAES v respublike Belarus: 30 let spustya [Medical Consequences of the Accident at the ChNPP in the Republic of Belarus: 30 Years Later].
Mediko-biologicheskiye problemy zhiznedeyatelnosti. 2016 ; 1(15) : 31-41 (in Russian).

4. Buzunov V.A., Krasnikova L.I., Pirogova E.A., Tereshchenko VM. and Voychulene Yu.S.

Epidemiologicheskiye issledovaniya I otsenka vliyaniya malykh doz ioniziruyushchego izlucheniya na razvitiye neopukholevykh zabolevaniy u postradavshikh vsledstviye avarii na ChAES

[Epidemiological Studies and Assessment of the Effect of

Small Doses of Ionizing

Radiation on the Development of Non-Tumor Diseases in the Sufferedfrom the Chernobyl Accident]. In : Problemy radiatsiinoi medytsyny ta radiobiolohii: zb. nauk. pr. [Problems of Radiation Medicine and Radiobiology Scientific Papers]. Kyiv; 2008 ; 13 : 5667 (in Russian).

5. Krasnikova L.I. and Buzunov V.A. Riski neopukholevoy patologii uchastnikov likvidatsii posledstviy Chernobylskoy avarii po dannym uglublennogo kliniko-epidemiologicheskogo monitoringa [Risks of Non-Tumor Pathology of the Participants in the Liquidation of the Consequences of the Chernobyl Accident According to In-Depth Clinical and Epidemiological Monitoring Findings]. In : Problemy radiatsiinoi medytsyny ta radiobiolohii: zb. nauk. pr. [Problems of Radiation Medicine and Radiobiology : Scientific Papers].Kyiv ; 2008 ; 13 : 199208 (in Russian).

6. Komarenko D.I., Yakymenko D.M., Moroz H.Z., Sarkisova E.O. and

Varshavska A.M. Stan orhaniv travlennia u postrazhdalykh vnaslidok avarii na ChAES [The State of Digestive Organs in the Suffered from the Accident at the ChNPP]. In :

Vozianov O.F., Bebeshko V.H. and Bazyka D.A. (Eds.). Medychni naslidky avarii na Chornobylskii atomnii elektrostantsii [Medical Consequenes of the Accident at the Chornobyl Nuclear
Power Plant]. Kyiv : DIA; 2007 :

318-326 (in Ukrainian).

7. Sarkisova E.O. et al. Patolohiia orhaniv systemy travlennia v osib, yaki zaznaly vplyvu malykh doz ionizuiuchoho vyprominiuvannia [Pathology of the Digestive System in thePeopleExposed to Low Doses of Ionizing Radiation]. In : BebeshkoV.H., Serdiuk A.M. and Bazyka D.A. (Eds.). Medychni naslidky Chornobylskoi katastrofy: 1986-2011 [Medical

Consequenes of the Chornobyl Disaster: 19862011]. Ternopil ; 2011 : 614634 (in Ukrainian).

8. Chumak V.V., Likhtarov I.A. and Repin V.S. Dozy oprominennia evakuiovanoho naseIennia [Dose of Radiation of the Evacuees]. In : Bariakhtar V.H. (ed.) Chornobylska katastrofa : monohrafiia [Chornobyl Disaster: Monograph]. Kyiv : Naukova dumka ; 1996 : 420424 (in Ukrainian).

9. Strapko N.P. and Pirogova E.A. Metodika epidemiologicheskogo monitoring obshchikh somaticheskikh zabolevaniy vzroslogo naseleniya, postradavshego vsledstviye avarii na ChAES: metodicheskiye rekomendatsii [The Methodology of Epidemiological Monitoring of General Somatic Diseases of the Adult Population Suffered from the Accident at the ChNPP: Guidelines]. Kiev ; 1993 : 32 p. (in Russian).

10. AlbomA. And Norrel C. Vvedeniye v sovremennuyu epidemiologiyu [Introduction to Modern Epidemiology].

Moscow ; 1996 : 122 p.

(in Russian).

Надійшла до редакції 17.02.2020 